\title{
Students' Integrated Science Process Skills Through CLIS Model
}

\author{
Emi Sulistri \\ College of Teacher Training and Education (STKIP) Singkawang, Singkawang, Indonesia \\ sulistriemi@gmail.com
}

Received: February $28^{\text {th }}, 2019$. Revised: March $8^{\text {th }}, 2019$. Accepted: March $9^{\text {th }}, 2019$

\section{Keywords :}

CLIS Model; Integrated Science

Process Skills

\begin{abstract}
This research was conducted for improve students' integrated science process skills such as aspects of interpreting data, formulating hypotheses, planning experiments, and applying concepts through the CLIS learning model. This quantitative research with pre-experimental design uses the one group pretest post-test design research design. The subjects in this study consisted of 27 students in one of the SMA Negeri on Singkawang City with the sampling technique in the form of a purposive sampling technique. The data collection technique in this study is tests of integrated science process skills that consists of 10 question multiple choice with five reasoned choices previously tested try with a reliability of 0.47 in the sufficient category. The increase in KPS analyzed by $N$-gain of 0.67 is in the medium category. It can be concluded that the application of CLIS learning model successfully enriching knowledges and can improve students' integrated science process skills.
\end{abstract}

\section{INTRODUCTION}

The effectiveness of applying student knowledge must involve students' intellectual, manual, and social abilities. These abilities are integrated into one skill, namely science process skills. Science process skills are very important for students as a provision to use scientific methods in developing science with the aim of gaining new knowledge or developing knowledge. As reported by Zeidan and Jayosi, students must integrate skills, knowledge, and attitudes to develop a better understanding of scientific concepts [1]. In addition to getting knowledge by involving students actively through observation and experiments to explain phenomena that occur in nature, science process skills are also needed to develop students' formal thinking skills in improving a country [2]. This is the reason the science process skills need to be improved.

Two science process skills that need to be improved, basic skills and integrated skills. Observing skills, using space / time relationships, concluding, measuring, communicating, classifying and predicting as basic science process skill variables and operationally defining, formulating hypotheses, interpreting data, experimenting, applying concepts and presenting information as integrated science process skills [3]. Chiappetta and Koballa introduce science process skills such as identifying problems, identifying and controlling variables, formulating hypotheses, interpreting data, 
operationally defining, reading/building graphics and experimenting as integrated science process skills and also as more complex skills than basic skills [4].

The improvment of students'Science Process Skills both basic and integrated, can use practical methods, because in practical activities psychomotor, cognitive, and also affective skills can be improved [5]. In practical activities, students can carry out observing, interpreting data, predicting, using tools and materials, planning practicums, communicating the results of lab work and asking questions. It's just that students' integrated science process skills are a little difficult to be trained. As explained by Akinbobola and Afolabi, that integrated science process skills are more difficult to improve because they are not used to being taught [6]. In addition, from the pre-test results of the Karamustafaoglu, it was shown that students' science process skills were the most problematic in the integrated science process skills [7]. One of the reasons is, besides practicum activities not always done because of the availability of time, teachers also often find it difficult to observe the science process skills that arise in each student, especially integrated science process skills. The limitations in this observation also make science process skills less in the spotlight, so that physics learning does not emphasize the aspects of students' science process skills [8]. In addition, the program implemented in our country begins with teacher-oriented learning that uses narrative methods and does not provide sufficient space for laboratory activities.

The problem of the low integration process skills of students is known based on interviews with physics teachers in one of the SMA Negeri Singkawang city. The results of the interview said that, even though students often saw demonstrations, students rarely used material tools when practicing. This is because the infrastructure does not allow for students do practicum . Because of students are rarely practicum, so students also rarely accept questions of integrated science process skills. This is in accordance with the results of tests conducted on 27 students whose average value of integrated science process skills of students is as much as $95 \%$ of students who get a value below the minimal completeness criteria (MCC) that has been determined which is 65.00 This result is different from the average value of students' basic science process skills, where there are $87 \%$ of students above the MCC. With this, the student's integrated science process skills proved low even lower than basic science process skills.

Based on these exposures, needed a learning model is that is able to improve students' integrated science process skills. The learning model used in this study is the learning model of childrens' learning in science (CLIS). This CLIS learning model is a physics learning model that pays attention to and considers the students' initial knowledge that might be obtained outside of school and provides a series of experiences in the form of real activities that are rational or understandable to students and allow to does social interactions. The most important factor in implementing the CLIS learning model that needs to be considered is creating an open learning situation and giving students freedom in expressing ideas, giving students the opportunity to ask freely with friends or teachers. Therefore, the CLIS learning model is expected to optimize student involvement in the learning process so that it minimizes the possibility of the emergence of negative activities that are not desired and can facilitate instilling the concept of physics in the learning process. In addition, the CLIS learning model can also teach science as a process, product, value, and attitude so that it can improve students' science process skills [9].

Application of the CLIS Model that contains a series of stages for forming knowledge processes into students' memory, so that the process can last long by generating student conceptual changes and encouraging students to carry out investigative activities, and improve various skills and perform process skills. Therefore the CLIS learning model can involve students in developing student learning in conducting experiments, making observations through demonstrations or experiments and finally explaining the results of their previous demonstrations and experiments. Thus when students experiment actively the students' science process skills will increase. By applying this CLIS model students can carry out observation and experiment activities. there are group discussion activities to strengthen ideas to guide students' science process skills to reinforce the conceptions that students 
already have. This means that this model clearly has compatibility with integrated science process skills because students are given the opportunity to conduct experiments on physics practicum.

\section{METHOD}

This quantitative research uses a pre-experimental design method using the research design of one group pretest-posttest design. The design of this study was applied by forming groups, which were then given a CLIS treatment model. The study sample was given treatment at certain intervals, the pretest was carried out before care and post-tests were carried out after treatment, the population involved all students of class X in one of the Singkawang City N High Schools and the sample consisted of 27 students with purposive sampling technique. The data collection technique is in the form of test students' science process skills in hot materi that was valid and reliablel. The integrated science process skills test sheet consists of 10 multiple choice questions with five reasonable answer choices, given during pre-test, before treatment and post-test after treatment. Technique Analysis of the results of tests of students' integrated science process skills are using the $\mathrm{N}$-gain equation.

\section{RESULTS AND DISCUSSIONS}

After obtaining the results of the pre test and post test data, the data were analyzed using a normalized gain test (N-gain). The $\mathrm{N}$-gain test is used to get an idea of increased every aspect of the students' integrated science process skills. The $\mathrm{N}$-gain results increase in every aspect of students' integrated science process skills shown in Fig 1.

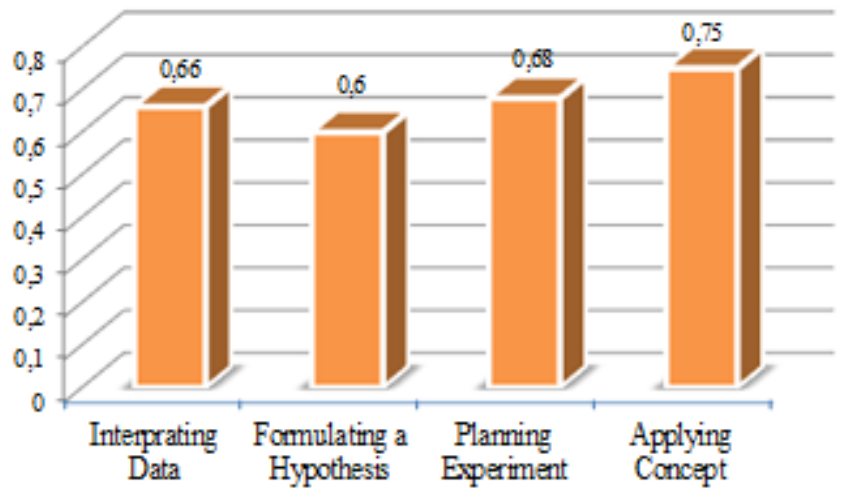

Fig 1. $N$-gain values for each aspect of the integrated science process skills

Figure 1 shows that the aspect of interpreting data has increased by 0.66 with the medium category. The aspect of formulating a hypothesis has increased by 0.60 with the medium category. The planning aspect of the experiment has increased by 0.68 with the medium category. And finally for the aspect of applying the concept experienced the highest increase of 0.75 in the high category. Overall, the improvement of students' integrated science process skills is 0.67 and is in the medium category.

The medium category on improving integrated science process skills is obtained from the results of $\mathrm{N}$ gain averages in each aspect of integrated science process skills. This proves that CLIS learning can help students to improve their integrated science process skills. This conclusion is reinforced by Ismail; Setiawan and Rusmana, stated that CLIS learning can direct students in various activities such as interpreting data, planning experiments, formulating hypotheses, applying concepts, even conducting experiments, so that CLIS learning can be influence students' integrated science process skills while its increase in the medium category [1][11]. 
Based on the results of data analysis it can be seen that in all aspects of integrated science process skills has increased. The highest increase in aspects is the aspect of applying the concept of 0.75 in the high category, this result is because students are able to apply scientific concepts that have been developed through experiments, and in that aspect students are trained twice at the CLIS learning stage. Strengthened by Aydogdu's research, the aspect of applying the concept is an aspect that invites students to participate in discovering the concept through the experiment activities they do in learning where students construct their own knowledge actively by conducting a practice to find a principle of results the practicum [12]. These aspects are trained at the stage of application of ideas. The planning aspect of the experiment was applied at the stage of construction of new ideas and evaluations, with an increase of 0.68. Improvement in this aspect is because students conduct experiments with the guidance of teachers and students can also design their own experiments as well as the ability of students to make observations, ask questions, and form hypotheses that are quite good. This is reinforce by Aydogdu's study, that students can conduct experiments at close range and we can learn these skills much better if we have our own experiments and design experiments in the laboratory itself [13]. In addition, it is also due to the right guidance given by the teacher so that students can plan experiments in accordance with the results of observations, formulation of the problems and hypotheses prepared beforehand [14].

In the aspect of interpreting the data that was trained at the stage of application of ideas, there was an increase in the medium category. The increase in this aspect is because students in the implementation stage of the idea are always given problems that direct students to be able to interpret the kalor experiment data they do well. This is confirmed by Aydogdu, that students are able to connect the results of observations and solve problems was in the experiment [12].

The lowest aspect of integrated science process skills is the aspect of formulating a hypothesis of 0.60 in the medium category. This is because students feel unfamiliar with answering questions related to application questions, so they tend to do experiments rather than formulating hypotheses. As found by Aydogdu, that student cannot prove his predictions for further [12]. Strengthened by the statements of Akinbobola and Afolabi, that integrated science process skills are more difficult to improve because they are not used to being taught [6]. Although the aspects of formulating hypotheses are in the zone of the lowest increase of other aspects of integrated science process skills, however students are able to prove the experiment and answer questions on the student worksheet given by the teacher. This is in accordance with the research of Hirca that when individuals can prove their predictions, they will arrive at a position that can encourage them to think further [15]. In connection with Piaget's theory, students are able to formulate problems and formulate hypotheses. Based on Piaget's cognitive development, high school level students are at the formal operational stage. At the formal operational stage students are able to formulate problems and hypotheses as the CLIS model stage. At the stage of ideas and rearrangement of ideas, an assimilation process occurs because students interact with the environment through observation, practical activities, and discussing. This is in reinforced by the results of Ismail study that the application of CLIS learning improves in formulating hypotheses compared to the application of conventional learning to the study of Physics [1].

Improved integrated science processes skills occur because they are relevant to Brunner's theory. The stages in CLIS learning are in accordance with the scientific method that accommodates students to make discoveries starting from formulating hypotheses, to the stage of applying concepts in experimental activities. Through the CLIS learning phase, students try to develop students' ideas about a particular problem in learning and reconstruct ideas based on the results of observations or experiments [16]. In addition, the increase in students' integrated science process skills occurs because students begin to be actively involved in finding concepts and conducting science activities obtained through direct activities in the form of appropriate practicum at each stage of CLIS learning. So that it can be said that through the activities in the CLIS learning model it can improve integrated science process skills. 


\section{CONCLUSION AND SUGGESTION}

Based Through the results of this study, it can be seen that the implementation of the learning model is increased as indicated by the better quality of learning in class X. The students seemed enthusiastic in following the learning process because they were faced with direct and pleasant learning. Poor student performance is caused by a lack of encouragement, innovation and human resources in making learning more interactive and enabling students to improve their skills especially in students' integrated science process skills. Students' science process skills increase because students have been trained to use science process skills such as formulating hypotheses, interpreting data, planning experiments and applying concepts through the learning stages of CLIS. In other words, these integrated process skills can be obtained by students through the stages of science instruction activities in CLIS learning. In short, CLIS learning has successfully enriched students' knowledge and improved their integrated science process skills.

There are some suggestions that can be taken into consideration. The suggestions are as follows. 1) For teachers it is recommended to use the CLIS learning model in the learning process because by using the model can improve integrated science process skills students with notes that the teacher must tighten the time of each stage of the CLIS model so that not much time is wasted, 2) For further researchers, this study can be used as a reference material and can be continued with a much wider sample and context so that better understanding is available.

\section{ACKNOWLEDGMENTS}

On this occasion the author expressed his deepest gratitude to physics teacher at the SMA Negeri Singkawang city, and as well as people who have given instructions, encouragement, suggestions and direction from the research plan to the completion of this article.

\section{REFERENCES}

[1] Zeidan, A. H., \& Jayosi, M. R. (2015). Science Process Skills and Attitudes toward Science among Palestinian Secondary School Students. World Journal of Education, 5(1): 13-24.

[2] Yuliani, H., Sunarno, W., \& Suparmi. (2012). Pembelajaran Fisika Dengan Pendekatan Keterampilan Proses Dengan Metode Eksperimen Dan Demonstrasi Ditinjau Dari Sikap Ilmiah Dan Kemampuan Analisis. Jurnal Inkuiri, 1(3).

[3] Tilakaratne, C. T. K., \& Ekanayake, T. M. S. S. K. Y. (2017). Achievement level of Science Process Skills of Junior Secondary Students: Based on a Sample of Grade Six and Seven Students from Sri Lanka. International Journal Of Environmental \& Science Education 2017, 12( 9): 2089-2108.

[4] Chiappetta, E., \& Koballa, T. (2002). Science Instruction in the Middle and Secondary Schools (5th ed). Upper Saddle River, NJ: Merrill Prentice Hall.

[5] Dwinjayanti, \& Siswaningsih. (2005). Pengembangan Keterampilan Proses Sains dalam Pembelajaran Kromatografi Lapis Tipis Melalui Praktikum Skala Mikro. Jurnal Inovasi Pendidikan Kimia, 2(2): 1-2.

[6] Akinbola, A. O., \& Afolabi, F. (2010). Analysis of Science Process Skills in West African Senior Secondary School Certificate Physics Practical Examinations in Nigeria. American Eurasian Journal of Scientific Research, 5(4): 234-240.

[7] Karamustafaoglu, S. (2011). Imporving The Science Process Skills Ability Of Science Student Teachers Using I Diagram. Eurasian Journal of Physics and Chemistry Education (EJPCE), 3(1): 26-38.

[8] Dimyati, \& Mudjiono. (2013). Belajar dan Pembelajaran. Jakarta:PT.Rineka Cipta.

[9] Wiguna. (2011). Pentingnya Konsepsi Awal dalam Pembelajaran Fisika. Jurnal Saintifika, 1(1): $1-2$. 
[10] Ismail, A. (2017). Penerapan Model Pembelajaran Children Learning In Science (CLIS) Berbantuan Multimedia Untuk Meningkatkan Keterampilan Proses Sains Siswa Sma Pada Pokok Bahasan Fluida. Jurnal Inovasi Pendidikan Fisika dan Riset Ilmiah, 1(2): 83-87.

[11] Setiawan, W. E., \& Rusmana, N. E. (2018). Penerapan Model Pembelajaran Children Learning In Science (CLIS) Dalam Pembelajaran Konsep Dasar IPA Untuk Meningkatkan Keterampilan Proses Sains Dan Sikap Ilmiah Mahasiswa Calon Guru IPA SD. Jurnal Pesona Dasar,6(2): 6674.

[12] Aydogdu, B. (2015). The investigation of science process skills of science teachers in terms of some variables. Educational Research and Reviews, 10(5): 1990-3839.

[13] Aydoğdu, B., \& Buldur, S. (2013). An Investigation of Pre-Service Elementary Teachers' Science Process Skills in Terms of Some Variables. Journal of Theorical Educational Sciences, 6(4): 520-534.

[14] Handayani, S. S. L., Suciati, \& Marjono. (2016). Peningkatan Keterampilan Proses Sains Pada Pembelajaran Biologi Melalui Penerapan Model Bounded Inquiry Lab. Bioedukasi, 9(2): 49-54.

[15] Hirca, N. (2015). Developing a Constructivist Proposal for Primary Teachers to Teach Science Process Skills: "Extended" Simple Science Experiments (ESSE). Asia-PacificForum on Science Learning and Teaching, 16(1): 345-450.

[16] Samatowa, U. (2011). Pembelajaran IPA Di Sekolah Dasar. Jakarta: PT.Indeks. 